T. Mueller-Lupp • H. A. Bauch • H. Erlenkeuser

J. Hefter $\cdot$ H. Kassens $\cdot$ J. Thiede

\title{
Changes in the deposition of terrestrial organic matter on the Laptev Sea shelf during the Holocene: evidence from stable carbon isotopes
}

Received: 21 December 1999 / Accepted: 10 July 2000 / Published online: 7 November 2000

(C) Springer-Verlag 2000

\begin{abstract}
Stable carbon isotope ratios in the organic fraction of surface sediments from the Laptev Sea shelf were analyzed in order to study the modern distribution pattern of terrestrial organic matter. The $\delta^{13} \mathrm{C}_{\text {org }}$ signature of the surface sediments range from $-26.6 \%$ near the coastal margin to $-22.8 \%$ in the north towards the outer shelf. Characterizing the possible sources of organic matter by their $\delta^{13} \mathrm{C}_{\text {org }}$ signature reveals that the terrestrial influence reaches further north in the eastern than in the western Laptev Sea. Downcore records of the $\delta^{13} \mathrm{C}_{\text {org }}$, measured on three AMS ${ }^{14} \mathrm{C}$-dated cores from water depths between 46 and $77 \mathrm{~m}$, specify the spatial and temporal changes in the deposition of terrestrial organic matter on the Laptev Sea shelf during the past $12.7 \mathrm{ka}$. The major depositional changes of terrestrial organic matter occurred between 11 and $7 \mathrm{ka}$ and comprised the main phase of the southward retreat of the coastline and of the river depocenters due to the postglacial sea level rise.
\end{abstract}

Keywords Stable carbon isotopes - Organic carbon · Land-shelf interaction · Holocene sediments · Laptev Sea $\cdot$ Siberia
T. Mueller-Lupp $(\bowtie) \cdot$ H. A. Bauch $\cdot$ H. Kassens

GEOMAR, Research Center for Marine Geosciences, Wischhofstrasse 1-3, 24148 Kiel, Germany

E-mail: tmueller-lupp@geomar.de

H. Erlenkeuser

Leibniz Laboratory for Radiometric Dating and

Stable Isotope Research, Kiel University, 24118 Kiel, Germany

H. A. Bauch · J. Hefter · J. Thiede

Alfred Wegener Institute for Polar and Marine Research, 27515 Bremerhaven, Germany

\section{Introduction}

The depositional environment of the broad and shallow Siberian shelf areas exerts a strong impact through the vast river system and their discharge and particulates. More than 20\% of the total Arctic continental runoff $\left(3300 \mathrm{~km}^{3}\right)$ is supplied by the rivers draining into the Laptev Sea (Aagard and Carmack 1989). Approximately $520 \mathrm{~km}^{3} /$ year of the total freshwater discharge of $700 \mathrm{~km}^{3} /$ year to the Laptev Sea is contributed only by the Lena River (Alabyan et al. 1995). Approximately $21 \times 10^{6}$ tons per year of suspended particulate material (Alabyan et al. 1995) and up to $1.2 \times 10^{6}$ tons per year of particulate organic carbon (POC; Rachold and Hubberten 1999) are transported by the rivers, most of it by the Lena. However, the actual amount of sediment reaching the Laptev Sea is still under discussion, because the portion of sediment that is deposited in the river deltas is not well known. Furthermore, the amount of material released by thermal erosion of the ice-rich permafrost coastline has only been partially quantified (Are 1999). The shelf sediments of the Laptev Sea not only contain evidence of the modern fluvial runoff but also record the depositional changes in the past. Whereas most of the shelf was exposed during the last glacial maximum (LGM), the postglacial sea-level rise led the shelf area to transform from a periglacial permafrost landscape into the modern shallow shelf sea (Bauch et al. 1999).

The ${ }^{13} \mathrm{C} /{ }^{12} \mathrm{C}$ ratio of the organic carbon in marine sediments has been used to specify the provenance of the organic fractions either derived from a terrestrial or a marine source (Hedges and Parker 1976; Tan and Edmond 1993; H. Erlenkeuser, unpublished data). This method is based on a general enrichment of ${ }^{13} \mathrm{C}$, by a few per mill on the delta scale, in marine organic matter compared with terrestrial material. Land plants using the $\mathrm{C}_{3}$ pathway of photosynthesis reveal $\delta^{13} \mathrm{C}$ 
values of approximately -25 to $-29 \%$ (Mook and Tan 1991), whereas the marine fraction of the sedimentary organic carbon is approximately $-20 \%$, with some variation related to the oceanic province. The intention of our studies is to trace the terrestrial organic matter using the organic stable carbon isotope composition in the sediments and to identify the depositional changes of terrestrial organic material during the Holocene history of the Laptev Sea. Due to the dominance of $\mathrm{C}_{3}$ plants in the catchment area of the Laptev Sea rivers, the terrestrial source is expected to provide a well-defined isotope signature which reliably helps to identify the contribution of the terrestrial source of organic matter to the surface and downcore sediments of the Laptev Sea shelf.

\section{Materials and methods}

\section{Sediment material}

Stable organic carbon isotope analyses were carried out on a total of 103 stations that cover a substantial part of the Laptev Sea shelf (Fig. 1). Three investigated sediment cores were obtained from the central (KD9502, PM9499) and outer shelf (PS2725). Core KD9502 from $46 \mathrm{~m}$ water depth and core PM9499 from $48 \mathrm{~m}$ water depth are located within the submarine channels of the Lena-Yana and Khatanga-Anabar rivers, respectively (Kassens et al. 1997; Kassens and Dmitrenko 1995). Core PS2725 was recovered from 77 $m$ water depth north of the New Siberian Islands (Rachor 1997).

For organic carbon isotope analysis, the bulk sediment samples were acidified with $2 \% \mathrm{HCl}(1 \mathrm{~h}$, $40{ }^{\circ} \mathrm{C}$ ) to remove carbonates, washed on a pre-combusted fiberglass filter, dried $\left(60^{\circ} \mathrm{C}\right)$, and combusted for $10 \mathrm{~min}$ at $900^{\circ} \mathrm{C}$ in an excess of 4.5 grade oxygen. The isotopically interfering $\mathrm{NO}_{\mathrm{x}}$ were reduced over copper at $450{ }^{\circ} \mathrm{C}$. The yield of $\mathrm{CO}_{2}$ was determined volumetrically and analyzed on a Finnigan-Mat Delta $\mathrm{E}$ isotope ratio mass spectrometer. The instrument was isotopically calibrated through the NBS 20 (carbonate) isotope standard $\left(\delta^{13} \mathrm{C}=-1.06 \%\right)$. The accuracy was checked using the IAEA NBS22 (oil) isotope reference material. The precision of the $\delta^{13} \mathrm{C}$ results is $\pm 0.02 \%$ PDB or better. The isotope composition is given in the $\delta^{13} \mathrm{C}$ vs $\mathrm{PDB}$ notation: $\delta^{13} \mathrm{C}\left[\%{ }^{\circ}\right]=\left[\left({ }^{13} \mathrm{C} /\right.\right.$ $\left.\left.{ }^{12} \mathrm{C}_{\text {sample }}{ }^{13} \mathrm{C} /{ }^{12} \mathrm{C}_{\text {standard }}\right) /\left({ }^{13} \mathrm{C} /{ }^{12} \mathrm{C}_{\text {standard }}\right)\right] \times 1000$.

To interpret the downcore carbon isotopic records in terms of paleoenvironmental changes, established chronological frameworks were used (Bauch et al. 1999; Stein and Fahl, 2000). The conventional ${ }^{14} \mathrm{C}$ ages were calibrated to calendar years (ka) using the program CALIB 4.1.2 (Stuiver and Reimer 1993; Stuiver et al. 1998). A reservoir effect of 400 years was applied (Bauch et al. 1999). Accumulation rates of total organic carbon (AccR TOC) were calculated on the basis of linear interpolation between the age

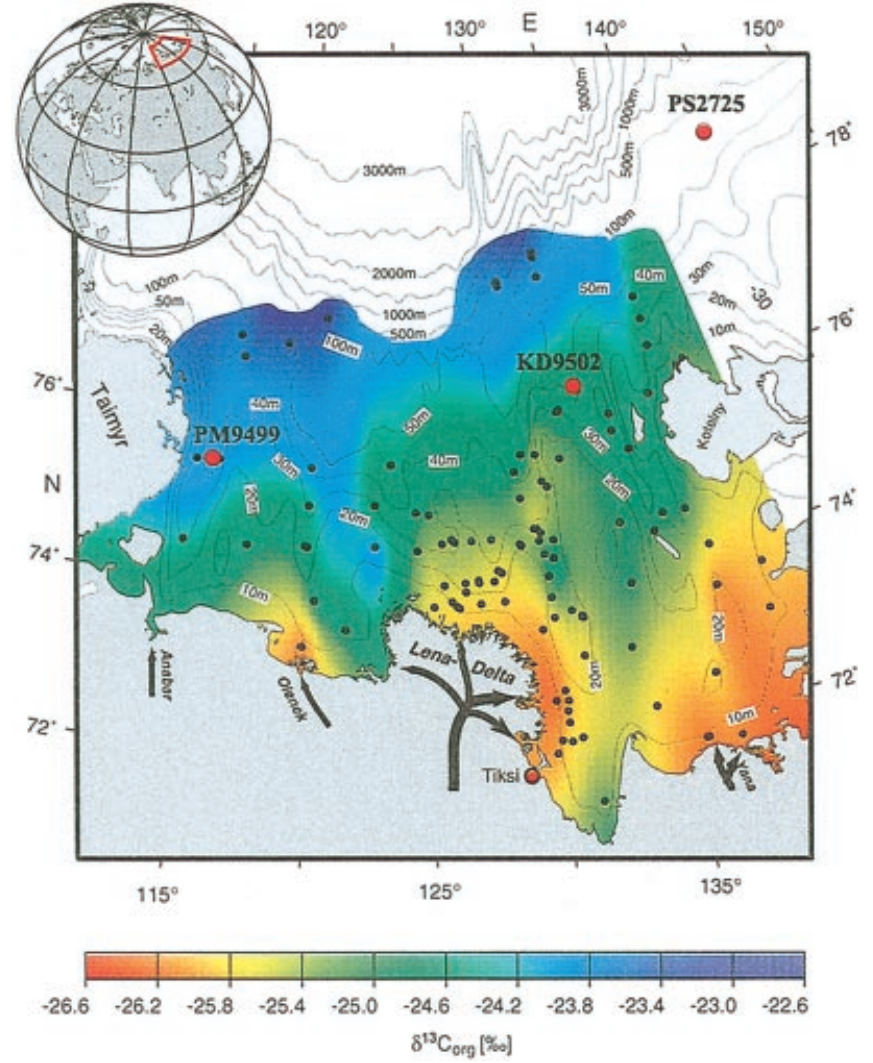

Fig. $1 \delta^{13} \mathrm{C}$ ratios of the organic fraction of the surface sediments from the Laptev Sea shelf. The distribution pattern was generated by gridding and linear interpolation between the data points (black dots)

points and consideration of the dry bulk density variations in the sediments.

\section{Results}

$\delta^{13} \mathrm{C}_{\text {org }}$ composition of the surface sediments

The $\delta^{13} \mathrm{C}_{\mathrm{org}}$ values of the surface sediments range from $-26.6 \%$ near the Lena Delta to $-22.8 \%$ on the continental slope, revealing a consistent trend toward isotopically heavier values from south to north (Fig. 1). The $\delta^{13} \mathrm{C}$ signature is lightest near the river mouths and gradually increases northward following to some extent the submarine valleys, which run in a south to north direction (Kleiber and Niessen 1999). The distribution pattern also reveals that lighter $\delta^{13} \mathrm{C}_{\text {org }}$ values extend further north in the eastern part of the Laptev Sea than in the western part. This obvious east-west gradient in $\delta^{13} \mathrm{C}_{\text {org }}$ values reflects the larger input of organic matter to the east (Rachold and Hubberten 1999) as compared with the western Laptev Sea, where marine conditions are more dominant (Dmitrenko et al. 1999).

The lightest values of $\delta^{13} \mathrm{C}$ observed near the mouths of the rivers Lena and Yana are in good 
agreement with the $\delta^{13} \mathrm{C}$ composition of the river-born particulate organic matter (POM). For the Lena River, Rachold and Hubberten (1999) report an average value of $-27.1 \pm 0.8 \%$, which is close to the values found east off the Lena River delta $(-26.6 \%)$, where the main branches discharge. Samples from north of the Yana River yield $-26.2 \%$, also matching the average isotopic composition of the riverine POM ( -25.9 $\pm 0.4 \%$; Rachold and Hubberten 1999).

Accumulation of TOC and $\delta^{13} \mathrm{C}_{\mathrm{org}}$ composition during the Holocene

The $\delta^{13} \mathrm{C}_{\text {org }}$ records in the two sediment cores from the central Laptev Sea (PM9499, KD9502) shelf show a distinct shift from isotopically lighter to heavier $\delta^{13} \mathrm{C}_{\text {org }}$ values (Fig. 2a), which is dated back in both cores to approximately $7 \mathrm{ka}$. This suggests a thorough change of the depositional conditions on the central Laptev Sea shelf during this time. A dominantly terrestrial source of organic matter, indicated by low $\delta^{13} \mathrm{C}_{\text {org }}$ values, is obvious in both cores prior to $7 \mathrm{ka}$. The increasing ${ }^{13} \mathrm{C} /{ }^{12} \mathrm{C}$ ratio coupled with decreasing accumulation rates of TOC underlines the decline of terrestrial organic matter supply to the central Laptev Sea shelf after $7 \mathrm{ka}$.

Also in the record of core PS2725 from the deeper outer shelf, this shift towards isotopically heavier $\delta^{13} \mathrm{C}_{\text {org }}$ values and decreasing accumulation rates of TOC becomes evident $2 \mathrm{ka}$ earlier. The development toward heavier $\delta^{13} \mathrm{C}_{\mathrm{org}}$ values seems to increase after 4 ka (Fig. 2b); however, a more precise dating of this younger change in the Holocene suffers from age uncertainties in this part of the core.

Prior to $10 \mathrm{ka}$ on the outer shelf, core PS2725 shows relatively heavy $\delta^{13} \mathrm{C}_{\text {org }}$ values. Although this section is not dated, our data and those of others (Stein and Fahl, 2000) indicate that this part of the core must have been deposited under different environmental settings compared with the remaining part. According to the heavy $\delta^{13} \mathrm{C}_{\text {org }}$ values, this core section may contain much older, reworked marine deposits.

\section{Discussion}

Distribution of terrestrial organic carbon in surface sediments

As revealed by our surface sediment data, the $\delta^{13} \mathrm{C}$ signature seems a feasible method to trace the deposition of the terrestrial organic matter on the Laptev Sea shelf. By this method it may also be possible to identify the main sources of organic matter by their $\delta^{13} \mathrm{C}$ signature. On the basis of our data, the terrestrial source of organic matter is isotopically identified by a $\delta^{13} \mathrm{C}_{\text {org }}$ of $-26.6 \%$, which conforms to the average sig- a) Central shelf

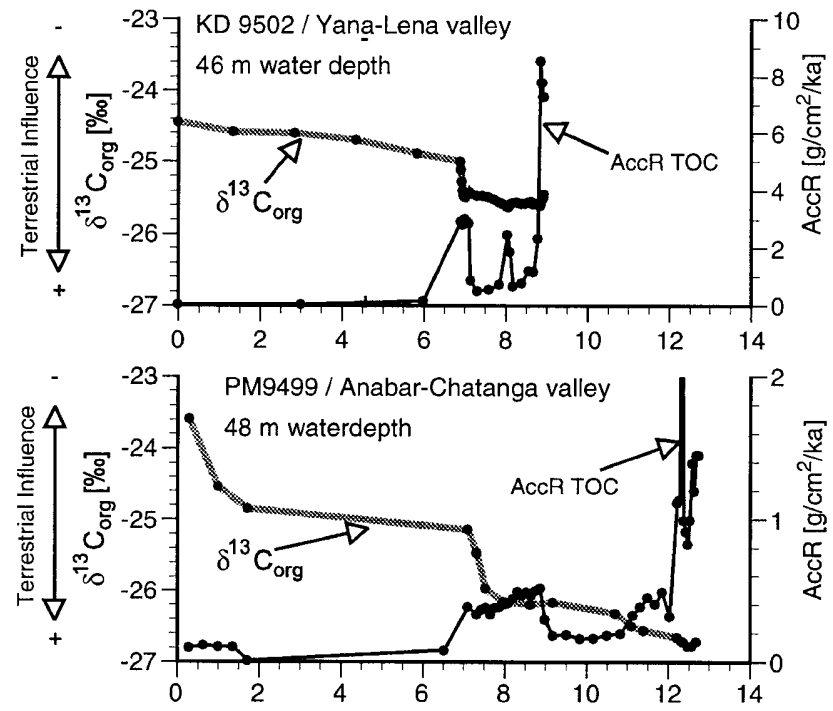

b) Outer shelf

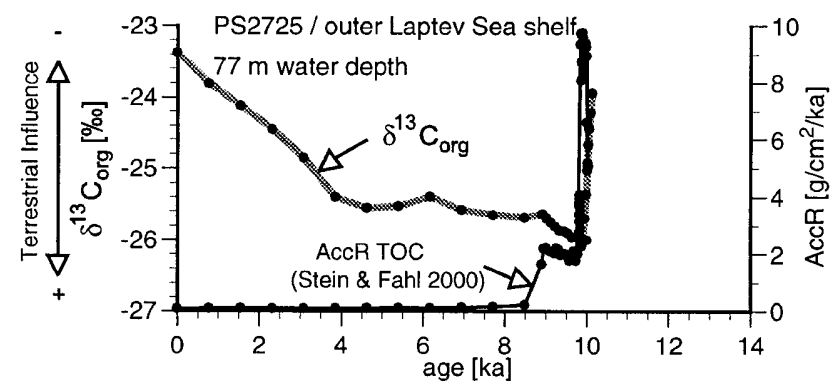

c)

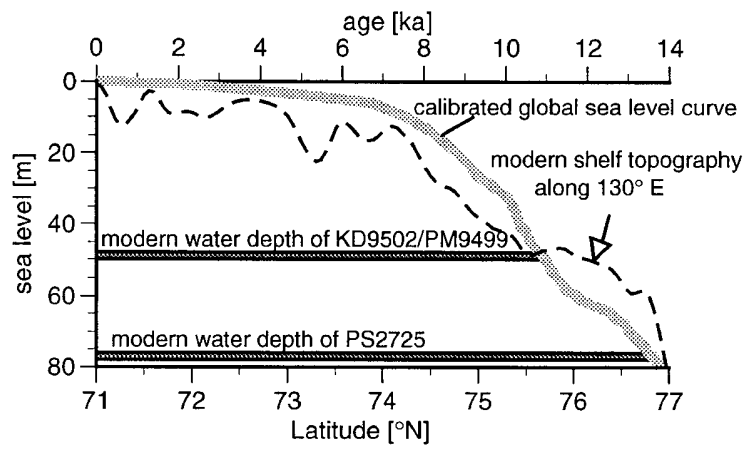

Fig. $2 \delta^{13} \mathrm{C}_{\text {org }}$ records and accumulation rates of TOC $(A c c R$ $T O C)$ for three cores indicating the Holocene depositional changes on a the central and b outer Laptev Sea shelves. c Profile of the modern Laptev Sea shelf topography (along $130 \mathrm{E}$ ) and the water depth of the investigated cores in comparison with the calibrated global sea-level curve (Fairbanks 1989). The global sea-level curve was calibrated to calendar years using the marine data set of CALIB 4.1.2 (Stuiver and Reimer 1993; Stuiver et al. 1998)

nature of POM, discharged by the main source, the Lena River. The river data of Rachold and Hubberten (1999) show that the signature of POM in the Siberian rivers is a mixture of two components, a detrital organic fraction with a $\delta^{13} \mathrm{C}_{\mathrm{org}}$ of $-25.0 \%$ and an isotopically lighter component with an average of $-31.0 \%$ 
which may be attributed to autochthonous riverine plankton. Rachold and Hubberten (1999) identified the detrital organic material as the main fraction of riverine POM, which is exported by the river runoff onto the Laptev Sea shelf. In addition, coastal material as another source of terrestrial input should not be neglected. Erosive processes, i.e., thermoabrasion and erosion of permafrost-affected coastal soils with a high content of organic carbon, should greatly imprint on the $\delta^{13} \mathrm{C}_{\text {org }}$ signature in Laptev Sea sediments. According to Are (1999), the coastline of the Laptev Sea retreats with a rate of $2-6 \mathrm{~m} / \mathrm{year}$ as a result of shore erosion. The amount of coastal erosion is estimated at $30 \times 10^{6} \mathrm{t} / \mathrm{year}$ for the total coast of the inner Laptev Sea, which is similar to or even higher than the riverine input of sediment. Large parts of the coastal area of the Laptev Sea are dominated by peaty and organic-rich permafrost soils including long sections of ice complexes (Rachold and Grigoryev 1999). Decomposition and mineralization of the organic matter in these soils is kept low by the harsh climatic conditions; thus, the $\delta^{13} \mathrm{C}$ signature of the original plant material remains well preserved (Gundelwein 1998). Analyses of modern plant material from typical tundra vegetation show $\delta^{13} \mathrm{C}_{\text {org }}$ values of -27.2 to -29.2\%o (Pfeiffer and Janssen 1993; Gundelwein 1998) and based on data from Carex sp. (-27.2\%), Eriophorum vaginatum $(-28.6 \%)$, and Dryas punctata $(-29.2 \%)$.

It is much more difficult to define a marine source of organic matter by its isotopic signature than the terrestrial source for the Laptev Sea region. The marine fraction of organic matter in the sediments is derived mainly from planktonic organisms. Their isotopic composition ranges from -20 to $-30 \%$ and is controlled by the isotopic fractionation between phytoplankton and the various fractions of dissolved inorganic carbon (DIC). The magnitude of this fractionation is related to temperature and to the $\mathrm{CO}_{2}$ partial pressure in the water (Fortugne and Duplessy 1981; Rau et al. 1992). Considering the generally low water temperature of the Arctic waters, the stable carbon isotope signatures should be isotopically lighter than in low- and mid-latitude waters; however, surface sediments of deep-sea cores from the Central Arctic Ocean reveal $\delta^{13} \mathrm{C}_{\text {org }}$ values between -21.4 and $-22.9 \%$ (Schubert 1995; $\mathrm{H}$. Erlenkeuser, unpublished data). The comparatively heavy carbon isotope composition found in Arctic Ocean sediments may relate to the influence of diatoms in the planktonic community, which partially use the $C_{4}$ cycle for carbon fixation (Voss 1991). Also microbial degradation of the planktonic organic detritus may lead to an increasing $\delta^{13} \mathrm{C}_{\text {org }}$ level in the sediments (Voss 1991). Despite the relatively heavy $\delta^{13} \mathrm{C}_{\text {org }}$ values in these surface sediments, several investigations of biomarkers and bulk organic parameters suggest that Arctic Ocean sediments have a strong terrestrial overprint (Schubert 1995; Schubert and Stein 1996; Fahl and Stein 1999; Stein and Fahl,
2000). For the Laptev Sea continental slope, Boucsein and Stein (2000) pointed out, applying the maceral analysis as a organic-carbon-source indicator, that only $20-40 \%$ of the organic carbon appears to be of marine origin.

Due to the strong riverine contribution of organic matter to the modern Laptev Sea shelf, the marine source seems to play a minor role. This is in accordance with previous surface sediment studies (Stein and Nürnberg 1995; Stein et al. 1999; Fahl and Stein 1999; Boucsein and Stein 2000) which revealed that the Laptev Sea, especially the eastern part, is characterized by a strong overprint of the terrestrial organic fraction on the total organic input. The resulting $\delta^{13} \mathrm{C}_{\text {org }}$ of the sedimentary mixture directly relates to the ratio of the two fractions, marine and terrestrial; the latter bears the greater potential of significant variations under the given settings of the Laptev Sea environment. Accordingly, we attributed the observed isotope variations to the effect of the sea-level rise, which induced the southward retreat of the coastline and the depocenters of the rivers and accordingly reduced the fluviatile impact on the coring sites. This view is also consistent with the modern findings of the $\delta^{13} \mathrm{C}_{\mathrm{org}}$ in the surface sediments which show lightest $\delta^{13} \mathrm{C}_{\text {org }}$ where the input rates of terrestrial matter are highest. Radiocarbon data from the bulk surface sediment of the eastern Laptev Sea reveal average radiocarbon ages of around 7000 years (Kuptsov and Lisitsin 1996). Apparently these relatively old ages are due to a mixture of older and younger organic carbon, eroded from soils and deposits of the river catchment areas. These ages are not indicative for surficial relict sediments, because various cores from the Laptev Sea shelf which were primarily dated on marine bivalves often reveal recent ages for the surface and show a continuous sediment accumulation up to the present (Bauch et al., in press).

\section{Holocene input of terrestrial organic matter}

For the paleoenvironmental interpretation it is necessary to consider that significant depositional changes occurred on the Laptev Sea shelf after the last glacial maximum (LGM). Because the sea level was lowered by more than $100 \mathrm{~m}$ during the LGM (Fairbanks 1989), huge areas of the shallow Laptev Sea shelf were exposed. With the postglacial sea-level rise, the shelf became flooded and the coastline, the river mouths, and their depocenters gradually retreated southward. According to the calibrated global sealevel curve (Fig. 2c), the sea level stood lower at 12.7 ka by approximately $70 \mathrm{~m}$ than at present and rose by approximately $60 \mathrm{~m}$ within the next 6000 years.

Based on our $\delta^{13} \mathrm{C}_{\text {org }}$ studies, the Holocene input of terrestrial organic matter onto the Laptev Sea shelf can be interpreted in three phases. An early phase, characterized by mainly terrestrial conditions, is 
marked in the western Laptev Sea between 12.7 and $11 \mathrm{ka}$ (Fig. 2a). The generally low $\delta^{13} \mathrm{C}_{\text {org }}$ values with a high amount of terrestrial plant debris embedded in laminated sediment sequences found in this phase reflect a dominantly riverine depositional character (Bauch et al. 1999).

The first appearance of marine bivalves at $11 \mathrm{ka}$ together with a slight increase of $\delta^{13} \mathrm{C}_{\text {org }}$ mark the onset of the second phase. In this transitional phase from 11 to $7 \mathrm{ka}$, the shallow Laptev Sea shelf became widely flooded, probably resulting in large-scale shelf and coastal erosion and, simultaneously, enhancing the rate of terrestrial organic matter released to the shelf. Large amounts of organic carbon accumulated as documented by high accumulation rates of TOC. The central shelf environment probably remained riverine influenced during this period of time. This is corroborated by low $\delta^{13} \mathrm{C}_{\text {org }}$ values (Fig. 2a), indicating continuously terrestrial fraction of organic matter and by abundances of freshwater algae (Kunz-Pirrung 1998), both indicating the proximity to the riverine source of these central sites before $8 \mathrm{ka}$. Palynological investigations in northern Siberia indicate a climatic change to warmer and moister conditions at $8 \mathrm{ka}$ (Naidina 1995; Melles et al. 1996). Thus, warmer and moisture conditions, and an expected enhanced river discharge, could have additionally increased the input of terrestrial organic material. As a result of the continuing transgression and the climate optimum in the Mid-Holocene, wave-based erosion and thermoabrasion of the coastal permafrost deposits were strong, making more terrestrial organic material available for distribution on the shelf. With the retreat of the coastline, the depocenters of the rivers moved further southward, reaching the central shelf between 9 and 7 ka. During this time when accumulation of organic carbon was at maximum, the estimated paleo-water depth, at the site of KD9502, was approximately $25 \mathrm{~m}$ (Fig. 2c), a depth where maximum sediment accumulation occurs presently in the Laptev Sea (Kuptsov and Lisitsin 1996). On the deeper outer shelf the maximum accumulation of organic matter is recorded between 10 and 9 ka (Stein and Fahl, 2000), due to the more northern position of the river mouths at this time.

The obvious decline in accumulation rates of TOC and the shift towards heavier stable carbon isotope composition after $7 \mathrm{ka}$ on the central shelf (Fig. 2a) marks the onset of the third phase, which is now characterized by a reduced depositional rate of terrestrial material. At $5 \mathrm{ka}$ the sea-level rise reached the Holocene maximum in the Laptev Sea and the modern environmental situation became established (Bauch et al., in press).

\section{Conclusion}

The depositional history of the Laptev Sea shelf during the Holocene is strongly coupled with the postglacial sea-level rise and the variations in the depositional environment. The $\delta^{13} \mathrm{C}_{\text {org }}$ analyses of surface sediments and three radiocarbon-dated sediment cores from the central and outer shelf are used as indicators for spatial and temporal changes in the deposition of terrestrial organic material onto the Laptev Sea shelf during the past $12.7 \mathrm{ka}$.

The modern distribution pattern of $\delta^{13} \mathrm{C}_{\mathrm{org}}$ in the Laptev Sea surface sediments is strongly influenced by the riverine input of terrestrial organic matter. Compared with the western Laptev Sea the terrestrial influence to the depositional realm of the eastern shelf reaches further north due to the high fluviatile discharge and input of terrestrial POM by the Lena and Yana rivers.

In a downcore record from the western Laptev Sea shelf, the low values of $\delta^{13} \mathrm{C}_{\text {org }}$ indicate that the source of organic carbon remained mainly terrestrial until 11 ka.

The first appearance of marine bivalves, low $\delta^{13} \mathrm{C}_{\mathrm{org}}$ values alongside with high accumulation of organic carbon characterize a second interval between 11 and $7 \mathrm{ka}$. This interval reflects the main transgressional phase of the Laptev Sea shelf.

The shift towards relatively low accumulation rates of TOC and a significant increase of $\delta^{13} \mathrm{C}_{\text {org }}$ on the central shelf marks the onset of a transition towards decreasing deposition of terrestrial organic matter at 7 ka. After this time, the sea level reached its Holocene maximum and, as a consequence, the main depocenters of the rivers moved their position southward, leading to the modern depositional environment.

Acknowledgements We thank V. Rachold, P. Meyers, and R. Stein for their constructive reviews and comments, which helped to improved the article. H. Cordt and M. Wollny are gratefully acknowledged for analytical assistance. This study was financially supported by the German Ministry of Education, Science, and Research within the bilateral Russian-German research project "System Laptev Sea 2000."

\section{References}

Aagard KC, Carmack E (1989) The role of sea-ice and other freshwater in the Arctic circulation. J Geophys Res 94:485-498

Alabyan AM, Chalov RS, Korotaev VN, Sidorchuk AY, Zaitsev AA (1995) Natural and technogenic water and sediment supply to the Laptev Sea. In: Kassens H, Piepenburg D, Thiede J, Timokhov L, Hubberten HW, Priamikov S (eds) RussianGerman Cooperation: Laptev Sea system. Rep Polar Res 176:265-271

Are FE (1999) The role of coastal retreat for sedimentation in the Laptev Sea. In: Kassens H, Bauch HA, Dmitrenko I, Eicken H, Hubberten HW, Melles M, Thiede J, Timokhov L (eds) Land-ocean systems in the Siberian Arctic: dynamics and history. Springer, Berlin Heidelberg New York, pp 287-295 
Bauch HA, Kassens H, Erlenkeuser H, Grootes PM, Thiede J (1999) Depositional environment of the Laptev Sea (Arctic Siberia) during the Holocene. Boreas 28:194-204

Bauch HA, Mueller-Lupp T, Spielhagen RF, Taldenkova E, Heinemeier J, Kassens H, Petryashov VV, Thiede J (in press) Radiocarbon dates of the Laptev Sea sediments: time constraints on the Holocene transgression of the Arctic Interior. Global Planet Change

Boucsein B, Stein R (2000) Particular organic matter in surface sediments of the Laptev Sea (Artic Ocean): application of maceral analysis as organic carbon-source-indicator. Geology 162:573-586

Dmitrenko I, Golovin P, Gribanov V, Kassens H (1999) Oceanographic causes for Transarctic ice transport of river discharge. In: Kassens H, Bauch HA, Dmitrenko I, Eicken H, Hubberten HW, Melles M, Thiede J, Timokhov L (eds) Land-ocean systems in the Siberian Arctic: dynamics and history. Springer, Berlin Heidelberg New York, pp 73-92

Fahl K, Stein R (1999) Biomarkers as organic carbon source and environmental indicators in the late Quaternary Arctic Ocean. Mar Chem 63:293-309

Fairbanks RG (1989) A 17-000-year glacio-eustatic sea level record: influence of glacial melting rates on the Younger Dryas event and deep ocean circulation. Nature 342:637-642

Fortugne MR, Duplessy JC (1981) Organic carbon isotope fractionation by marine plankton in the temperature range 1 to $31^{\circ} \mathrm{C}$. Oceanol Acta 4:85-90

Gundelwein A (1998) Eigenschaften und Umsetzung organischer Substanz in nordsibirischen Permafrostböden. Hamburger Bodenkundliche Arb 39:1-162

Hedges JI, Parker PL (1976) Land-derived organic matter in surface sediments from the Gulf of Mexico. Geochim Cosmochim Acta 40:1019-1029

Kassens H, Dmitrenko I (1995) The TRANSDRIFT II expedition to the Laptev Sea. Rep Polar Res 182:1-180

Kassens H, Dmitrenko I, Timokhov L, Thiede J (1997) The TRANSDRIFT III expedition: freeze-up studies in the Laptev Sea. Rep Polar Res 248:1-210

Kleiber HP, Niessen F (1999) Late Pleistocene paleoriver channels on the Laptev Sea shelf: implications from sub-bottom profiling. In: Kassens H, Bauch HA, Dmitrenko I, Eicken H, Hubberten HW, Melles M, Thiede J, Timokhov L (eds) Land-ocean systems in the Siberian Arctic: dynamics and history. Springer, Berlin Heidelberg New York, pp 657-665

Kunz-Pirrung M (1998) Rekonstruktion der Oberflächenwassermassen der östlichen Laptevsee im Holozän anhand von aquatischen Palynomorhen. Berichte Polarforsch 281:1-117

Kuptsov VM, Lisitsin AP (1996) Radiocarbon of Quaternary along shore and bottom deposits of the Lena and the Laptev Sea sediments. Mar Chem 53:301-311

Melles M, Siegert C, Hahne J, Hubberten HW (1996) Klima und Umweltgeschichte des nördlichen Mittelsibiriens im Spätquartär - erste Ergebnisse. Geowissenschaften 14:376-380

Mook WG, Tan FC (1991) Stable carbon isotopes in rivers and estuaries. In: Degens ET, Kempe S, Richey JE (eds) Major world rivers. SCOPE, Wiley, pp 245-264

Naidina OD (1995) Holocene climatic, vegetation and pollen data of Siberia adjacent to the Laptev Sea. In: Kassens H, Piepenburg D, Thiede J, Timokhov L, Hubberten HW, Priamikov S (eds) Russian-German Cooperation: Laptev Sea system, Rep Polar Res 176:235-253
Pfeiffer EM, Janssen H (1993) Characterization of organic carbon, using the $\delta^{13} \mathrm{C}$-value of a permafrost site in the KolymaIndirka lowland, Northeast Siberia. Proc Meeting on the Classification, Correlation and Management of Permafrost Affected Soils. Lincoln, Nebraska pp 90-98

Rachold V Grigoryev N (1999) Russian-German Cooperation System Laptev Sea 2000: the Lena Delta 1998 expedition. Rep Polar Res 315:259

Rachold V, Hubberten HW (1999) Carbon isotope composition of particular organic material in east Siberian rivers. In: Kassens H, Bauch HA, Dmitrenko I, Eicken H, Hubberten HW, Melles M, Thiede J, Timokhov L (eds) Land-ocean systems in the Siberian Arctic: dynamics and history. Springer, Berlin Heidelberg New York, pp 223-238

Rachor E (1997) Scientific cruise report of the Arctic Expedition ARK-XI/1 of RV "Polarstern" in 1995. Rep Polar Res 226:1-157

Rau GH, Takahaschi T, Marais DJD, Repeta DJ, Martin JH (1992) The relationship between $\delta^{13} \mathrm{C}$ of organic matter and $\mathrm{CO}_{2}(\mathrm{aq})$ in ocean surface water: data from JGOFS site in the northeast Atlantic and a model. Geochim Cosmochim Acta 56:1412-1419

Schubert CJ (1995) Organischer Kohlenstoff im spätquartären Sedimenten des Arktischen Ozeans: Terrigener Eintrag und marine Produktivität. Berichte Polarforsch 177:1-178

Schubert CJ, Stein R (1996) Deposition of organic carbon in Arctic Ocean sediments: terrigenous supply vs marine productivity. Org Geochem 24:421-436

Stein R, Fahl K (2000) Holocene accumulation of organic carbon at the Laptev Sea continental margin (Arctic Ocean): sources, pathways, and sinks. Geo-Mar Lett 20:27-36

Stein R, Nürnberg D (1995) Productivity proxies: organic carbon and biogenic opal in surface sediments from the Laptev Sea shelf and the adjacent continental slope. In: Kassens H, Piepenburg D, Thiede J, Timokhov L, Hubberten HW, Priamikov S (eds) Russian-German cooperation: Laptev Sea system. Rep Polar Res 176:286-296

Stein R, Fahl K, Niessen F, Siebold M (1999) Late Quaternary organic carbon and biomarker records from the Laptev Sea continental margin (Arctic Ocean): implications for organic carbon flux and composition. In: Kassens H, Bauch HA, Dmitrenko I, Eicken H, Hubberten HW, Melles M, Thiede J, Timokhov L (eds) Land-ocean systems in the Siberian Arctic: dynamics and history. Springer, Berlin Heidelberg New York, pp 635-655

Stuiver M, Reimer PJ (1993) Extended ${ }^{14} \mathrm{C}$ data base and revised CALIB $3.0{ }^{14} \mathrm{C}$ calibration program. In: Stuiver $\mathrm{M}$, Long A, Kra RS (eds) Calibration 1993. Radiocarbon 35:215-230

Stuiver M, Reimer PJ, Bard E, Beck JW, Burr GS, Hughen KA, Cromer B, McCormic G, van der Plicht J, Spurk M (1998) INTCAL 98 radiocarbon age calibration, 24,000-0 cal BP. Radiocarbon 40:1041-1083

Tan FC, Edmond JM (1993) Carbon isotope geochemistry of the Orinoco Basin. Estuarine Coast Shelf Sci 36:541-547

Voss M (1991) Räumliche und zeitliche Verteilung stabiler Isotope $\left(\delta^{15} \mathrm{~N}, \delta^{13} \mathrm{C}\right)$ in suspendierten und sedimentierten Partikel im Nördlichen Nordatlantik. Berichte Sonderforschungsbereich 313:102 